\title{
The Relationship between Organizational Trust and Organizational Silence with Job Satisfaction and Organizational Commitment of the Employees of University
}

\author{
Parastoo Gashtasebi Fard ${ }^{1} \&$ Fariba Karimi ${ }^{2}$ \\ ${ }^{1}$ Department of Educational Sciences, Isfahan (Khorasgan) Branch, Islamic Azad University, Isfahan, Iran \\ Correspondence: Fariba Karimi, Department of Educational Sciences, Isfahan (Khorasgan) Branch, Islamic \\ Azad University, Isfahan, Iran. E-mail: faribakarimi2005@yahoo.com
}

Received: July 15, 2015 Accepted: August 16, 2015 Online Published: October 28, 2015

doi:10.5539/ies.v8n11p219

URL: http://dx.doi.org/10.5539/ies.v8n11p219

\begin{abstract}
This study aimed to investigate the structural model between organizational trust and organizational silence with job satisfaction and organizational commitment of the employees of Islamic Azad University of Isfahan, (Khorasgan) branch. The study method is descriptive-correlation. The study population is the employees of Islamic Azad University of Isfahan branch (Khorasgan) as 340. 180 employees are selected by simple random method and sampling Table (Krejcie \& Morgan, 1970). The questionnaires of organizational trust (Ellonen et al., 2008) and organizational silence questionnaires, job satisfaction and organizational commitment (Bouradas \& Vakola, 2005). For analysis of study findings, Pearson correlation coefficient and structural equations modeling are applied. The results of study showed that organizational trust had inverse and significant relation with organizational silence and had positive and significant relationship with job satisfaction and organizational commitment. Also, there was an inverse and significant relationship between organizational silence and job satisfaction and organizational commitment. The results of structural equations modeling showed that organizational trust had direct impact on organizational silence (-64) organizational commitment (0.45) and job satisfaction (0.39) and has indirect impact via organizational silence on organizational commitment $(0.29)$ and job satisfaction (0.29). Also, organizational silence had direct impact on organizational commitment and job satisfaction (-45). The model has good conditions in terms of fitness indices and fitness data.
\end{abstract}

Keywords: organizational trust, organizational silence, job satisfaction, organizational commitment, employees of Islamic Azad University

\section{Introduction}

The management based on trust is a new expression of old thoughts and its position in observed well in current relations and using its mechanisms can be effective on achieving good individual and organizational results. The authorities believe that trust can lead to collaboration among people, groups and organizations. Today, organizations attempt to search new solutions to improve participation among people, groups and use their effects (Jones \& George, 1998). All organizational relations are established based on trust. It is important that organization managers and employees consider importance of trust, promotion and their role in trust (Fitzroy, 2007). Organizational trust is raised as basic need for organization, society integration and creating democracy in organizations. Today, trust is created as an important structure in wide range of management (Horn-Nord et al., 2014). Organizational trust refers to the positive expectations of people and the expectations of organization members about competence, reliability and benevolence including Interpersonal trust and Institutional Trust (Mayer et al., 1995). Interpersonal trust is divided into Lateral Trust and Vertical Trust. Lateral Trust is defined the trust of employees with each other and vertical trust is the trust between the employees and managers in organization (Ellonene et al., 2008). Institutional Trust refers to one's belief regarding the position of institutional structures to fulfill the successful attitude and future of a person (Mcknight et al., 1998).

Thus, the process of organizational trust creation in public organizations is the responsibility of qualified managers and leaders. The role of managers and leaders in reforms in organization is of great importance. For successful feedback and observation of advanced organizational behavior, we need high level of interpersonal trust among the co-workers in organization (Bakiev, 2013). In new era, responding the basic needs of employees 
in each organization is on priority and one of the most important needs of employees in organization is establishing trust among them and organization. High level of trust in organization creates low costs of evaluation and other control mechanisms (Khanifar et al., 2009). Trust in organization refers to the relationship established among the employees and organization based on messages regarding organizational expectations and perception of employees of the measurements of organization managers.

Organizational trust is of great importance in success of organizations. Trust is an important issue for most organizations as it can have great advantages for organization. Organizational trust is defined as psychological state providing a feedback of how employees perceive the problems in the situations in which the organization is endangered (Vakola \& Bouradas, 2011). The organization managers should perceive complexity and multidimensional nature of trust and its impact on Organizational Commitment, job satisfaction and dynamics of the relations between these three variables (Sheik-Mohamed et al., 2012). Today, due to increasing competition, high expectations of customers and quality, the organizations expect the employees to be involved in responsibility acceptance and innovation. In such era, for their survival, the organizations need the people reacting well for environmental challenges and don't fear sharing knowledge and information and attempt for their beliefs and beliefs of their teams. Although, these items emphasis on empowerment and open communication channels, most of employees report that their organizations don't support communication, knowledge sharing and information and these items are the reasons of failure of change management plans. One of the major barriers of change plans is the lack of information, trust namely the new items as called organizational silence by Morrison and Milliken (2000). However, employees silence includes organizations and there are a few scientific investigations about employees' silence. Morrison \& Milliken believe that silence is turned into a strong force in organizations but serious studies are not performed in this regard. Morrison \& Milliken have shown that organizational silence is social phenomenon created in an organizational level and is affected by most of organizational features as decision making processes, management, culture and perceptions of employees. Although theorists state organizational commitment, job satisfaction or lack of job satisfaction as predictors or opinion and silence factors, Morrison \& Milliken emphasis on these variables as outcomes of organizational silence. Morrison \& Milliken show that silence leads to cognitive in coordination among other variables and they have low motivation, job satisfaction and commitment. Job satisfaction is one's general attitude to his job. When employees join an organization have set of desires, needs and past experiences and create job expectations. One of these needs is tendency to achieve training, learning and scientific progress, suitable benefits, tendency to job promotion, security and suitable work conditions and their satisfaction in organization leads to job satisfaction of employees (Maleknia et al., 2011).

Some managers emphasize on this fact that employees satisfaction can be increased via reward and motivation to work. Although mostly employees focus on work economic aspects, they are interested in doing the valuable tasks and high job independence in their work. If these employees are encountered with some barriers in their job expectations, it leads to silence and low job satisfaction (Zareematin et al., 2011). The trust in organization and control of organizational silence lead to job satisfaction of employees and organizational commitment. Job satisfaction is formed after entering the organization but organizational commitment is developed slowly. Job satisfaction is the pre-requirement of organizational commitment. Organizational commitment is described widely in management and literature of organizational behavior as key factor in relations between people and organizations. Organizational commitment can lead to useful outcomes as increasing the effectiveness, efficiency and productivity and reduction of trading volume and absence in individual and organizational levels (Kaneshiro, 2008). In most conditions, the important point is that employees don't have required experience for perception of important issues and they don't have power, they are not good team actors and their behavior creates problems and negative feeling of their participation. Managers believe that employees encourage themselves to speak clearly but they apply formal methods to cope up with opposite views of employees. Indeed, organizational silence components, Top management attitudes to silence, Supervisor's attitudes to silence, Communication opportunities and Employees silence behavior explain the condition of this organizational phenomenon among the employees (Vakola \& Bouradas, 2011). Organizational silence is associated with limitation of effectiveness of or organizational decision making and change processes. The problem of organizations is that most organizations are sad regarding the very low opinion of employees. In such condition, decision making quality and changes in organization are reduced. Also, organizational silence avoids organizational development and changes by avoiding negative feedback and the organization cannot correct the errors. Thus, without negative feedbacks, the errors are increased and as corrective activities are not performed as necessary, organizational silence and its eliminating methods are of great importance in organizational issues and require serious consideration of organization managers (Panahi \& Danaeifard, 2010). The far of management of negative feedbacks from employees is due to endangering the benefits of their situation and perception of employees of 
tacit beliefs of management about them. These tacit beliefs include some management thoughts as employees only consider their personal benefits. Organization management understands that it knows the best and difference of beliefs in nature are harmful issues for organizations. These issues are management beliefs and it is possible that none of them are real in organization but create harmful emotions as fear, deception and anger in organization employees and create employees silence (Slade, 2008). Due to increasing competition, high expectations of customers, quality as the result of continuous change world, organizations expect their employees to be involved in innovation and responsibility acceptance. In such era, for survival, organizations need the people reacting well for environmental challenges and don't fear of sharing knowledge and information and attempt for their own beliefs and the beliefs of their teams. Although these items emphasize on empowerment and open communication channels, most of employees report that their organizations don't support communication, knowledge and information sharing and these items are the reasons of failure of change management plans (Vakola \& Bouradas, 2011).

\section{Literature Review}

Callaway et al. (2007) in a study "relationship between organizational trust and job satisfaction (An analysis in Federal organization of US) found that trust in organization led into job satisfaction of employees. Indeed, there was relationship between organizational trust and job satisfaction. It means that the higher the organizational trust, the highly improved the job satisfaction of employees.

Binikos (2010) in the study "Sounds of silence: Organizational trust and decisions to blow the whistle" found a significant and negative relationship between 'organizational trust' and 'keep quiet'. Indicating that as organizational trust increases, the likelihood of keeping quiet decreases and decision making to cope up with whistle blowing in organization leads to distrust among the employees of organization.

Panahi and Danaeifard (2010) in the study "analysis of job attitudes of employees of state organizations, explaining organizational silence and organization silence behavior climate" found that in silence behavior dimension, there was a negative and significant relationship with organization commitment. The higher the silence behavior of employees in organization, the lower the organizational commitment of employees. Also, there was a negative and significant relationship in management attitudes to silence, Supervisor's attitudes to silence and organizational commitment. The highly negative the attitude of management and supervisor to silence, the lower the organizational commitment of employees. In their studies, they found that there was a negative and significant relationship between organizational silence in silence behavior of employees and job satisfaction. It means that the higher the silence behavior of organizations in organization, the lower the job satisfaction of employees. Also, the results of findings showed that in top management attitude to silence and supervisor attitude to silence, there was relationship with job satisfaction. It means that the highly negative the attitudes of top management to employees, the lower the job satisfaction and the highly the negative attitudes of supervisors to employees, the lower their job satisfaction.

Khorshid and Yazdani (2012) in a stud y "the investigation of the relationship between trust, contrast and organizational belonging by considering the moderating impact of organizational commitment" found that trust of employees to organization and contrast norms in organization had positive and significant impact on trust of employees. In addition, among various dimensions of organizational commitment, emotional commitment of employees to organization, the relations of trust of employees to organization with their organizational belonging and duality norms in organization adjust organizational belonging of employees positively and significantly.

Bakiev (2013) in a study "the impact of interpersonal trust and organizational commitment on organizational perception performance" found that there was a positive and significant relationship between interpersonal trust and organizational commitment. The results of studies showed that interpersonal trust in employees and creating trustful climate led into high level of commitment and performance improvement

Deniz et al. (2013) in a study "the relationship between silence of employees and organizational commitment in a private health company" supported the negative and significant relationship between organizational silence and organizational commitment. They found that organizational silence was effective on employees' performance and organizational commitment.

Lee et al. (2013) in the study "the impact of CSR on organizational trust, job satisfaction of employees and customer orientation" found that CSR had positive and significant impact on organizational trust and this organizational trust had positive and significant relationship with job satisfaction and this had positive impact on customer orientation.

Partoniya (2014) in the study "the impact of trust on organizational silence and its challenges in Iran" found that 
there was an inverse and significant relationship between trust and organizational silence. Organizational silence was a barrier for organizational success and trust could reduce the impact of this item. Trust was an important factor to help the organization management to reduce silence impacts in organization.

\section{The Research Hypotheses}

The present study aimed to determine the model of relations between organizational trust and organizational silence with job satisfaction and organizational commitment of employees of Islamic Azad University of Khorasgan branch (Isfahan). The following hypotheses are raised based on the study purpose:

- Organizational trust is effective on organizational silence.

- Organizational trust is effective on job satisfaction.

- Organizational trust is effective on organizational commitment.

- Organizational trust is effective on job satisfaction via organizational silence.

- Organizational trust is effective on organizational commitment via organizational silence.

- Organizational silence is effective on job satisfaction.

- Organizational silence is effective on organizational commitment.

Based on the study hypotheses, the conceptual model of study is shown in Figure 1.

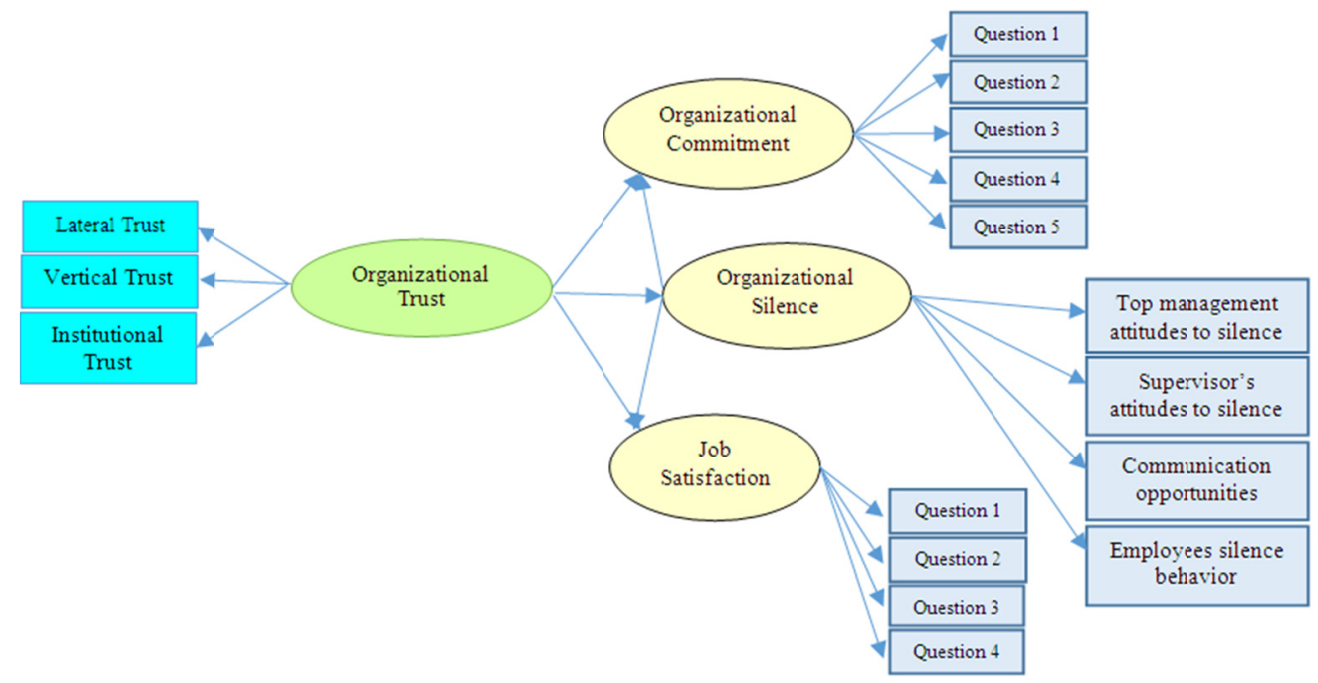

Figure 1. The conceptual model

\section{Research Method}

The study population is employees of Islamic Azad University of branch Isfahan (Khorasgan) as 340. 180 Employees are selected by Krejcie and Morgan (1970) table and simple random sampling method. The demographic features of study sample showed that among 180 samples, $55.5 \%$ of participants were men and $41.8 \%$ women. $24.4 \%$ had Diploma and associate, $66.5 \%$ BA and MA and $7.7 \%$ with PHD degree. $39 \%$ of employees had experience of 5 to 10 years, $30.2 \%$ experience of $11-20$ years and $26.9 \%$ with experience of higher than 20 years.

\section{Instrument}

The data collection measure is organizational trust based on lateral trust, vertical trust and institutional trust by Ellonen et al. (2008) with 48 items and 5-item Likert scale. The reliability of this questionnaire is 0.77 by Cronbach's alpha. Vakola and Bouradas (2005) questionnaire of organizational silence is used to evaluate organizational silence with 22 items and 5-item Likert scale. This questionnaire is based on organizational silence components as (Top management attitudes to silence, Supervisor's attitudes to silence, Communication opportunities and Employees silence behavior). The reliability of this questionnaire is 0.80 by Cronbach's alpha. To evaluate job satisfaction, Vakola and Bouradas (2005) questionnaire with 4 questions and 5-item Likert scale 
with reliability 0.82 based on Cronbach's alpha coefficient is used. To evaluate organizational commitment, Vakola and Bouradas (2005) questionnaire with 5 questions with 5 -item Likert scale and reliability 0.75 by Cronbach's alpha are applied.

\section{Data Analysis}

The study is descriptive-correlation. The study is applied based on study nature. Pearson correlation coefficient is used for analysis of study fin dings and structural equations modeling is used by SPSS, version 19 and LISREL 8.8 software.

\section{Result}

Table 1. Mean, standard deviation and internal correlation among research variable

\begin{tabular}{llcccccc}
\hline & Research variable & Mean & Standard deviation & 1 & 2 & 3 & 4 \\
\hline 1 & Organizational Trust & 144.68 & 34.70 & - & & & \\
2 & Organizational Silence & 68.16 & 16.82 & $\star \star \star-0.807$ & - & \\
3 & Job Satisfaction & 11.75 & 3.86 & $\star \star 0.727$ & $\star \star-0.756$ & - & \\
4 & Organizational Commitment & 15.46 & 3.68 & $\star \star 0.746$ & $\star \star-0.700$ & $\star \star 0.743$ & - \\
\hline
\end{tabular}

$\star \star \overline{\mathrm{P}<0.01 \text {. }}$

The results of Table 1 show that there was an inverse and significant relationship between organizational trust and organizational silence $(\mathrm{r}=-0.807)$. Also, there is a positive and significant relationship between job satisfaction $(\mathrm{r}=0.727)$ and organizational commitment $(\mathrm{r}=0.746)$ with organizational trust. The results show that there is an inverse and significant relationship between organizational silence and job satisfaction $(\mathrm{r}=-0.756)$ and organizational commitment $(\mathrm{r}=-0.700)$. To study the study hypotheses, structural equations model and Lisrel software are used. The results of modeling of structural equations for final model of study are presented.

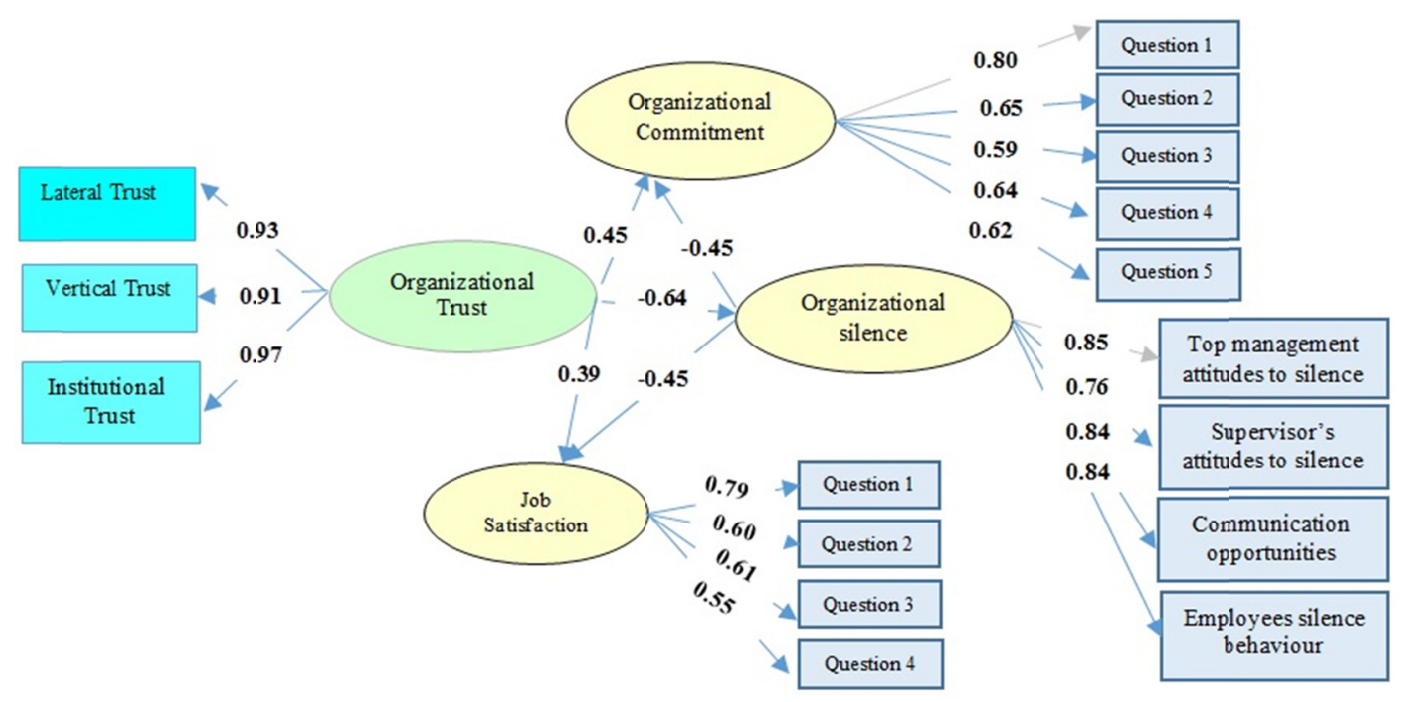

Figure 2. The original model of research

As shown in Figure 2, organizational trust has direct impact on organizational commitment (0.45), organizational silence (-0.64) and job satisfaction (0.39). In this study, organizational silence variable is considered as moderating variable. Organizational trust has indirect impact via organizational silence on job satisfaction and organizational commitment (0.29). Organizational silence has direct impact on organizational commitment and job satisfaction (-0.45). 
Table 2. Results of structural equation modeling to final patterns research

\begin{tabular}{|c|c|c|c|c|c|c|c|c|c|c|}
\hline Considered routes for the final model & B & $\beta$ & SE & $\mathrm{R}^{2}$ & $\mathrm{X}^{2} / \mathrm{df}$ & $\mathrm{p}$ & G.F.I & A.G.F.I & N.F.I & RMSEA \\
\hline $\begin{array}{l}\text { Organizational Trust- Organizational } \\
\text { Commitment }\end{array}$ & 0.45 & 0.45 & 0.086 & 0.20 & & & & & & \\
\hline Organizational Trust-Organizational Silence & -0.64 & -0.64 & 0.077 & 0.41 & & & & & & \\
\hline Organizational Trust-Job Satisfaction & 0.38 & 0.39 & 0.094 & 0.15 & 0.756 & 0.967 & 0.95 & 0.93 & 0.98 & 0.00 \\
\hline $\begin{array}{l}\text { Organizational Trust -Organizational Silence - } \\
\text { Job Satisfaction }\end{array}$ & 0.28 & 0.29 & 0.07 & 0.08 & & & & & & \\
\hline $\begin{array}{l}\text { Organizational Trust- Organizational } \\
\text { Silence-Organizational Commitment }\end{array}$ & 0.29 & 0.29 & 0.06 & 0.08 & & & & & & \\
\hline $\begin{array}{l}\text { Organizational Silence- Organizational } \\
\text { Commitment }\end{array}$ & -0.44 & -0.45 & 0.088 & 0.20 & & & & & & \\
\hline Organizational Silence- Job Satisfaction & -0.45 & -0.45 & 0.097 & 0.20 & & & & & & \\
\hline
\end{tabular}

The fitness indices of model in Table 2 show that the model has good fitness, it means that Chi-square indicates numerical value as 0.756 . The standard value of P-Value should be higher than 0.05 that the model is supported and this index is 0.967 in this model indicating suitability of model fitness. RMSEA index is deviation test in degree of freedom and is 0.000 in the present model and it indicates good fitness. One the other indices in the present model is GFI. This index has bigger fitness compared to other indices and it should be equal or bigger than 0.9 to verify the model. This index in the present model is 0.95 and has good fitness. AGFI index is corrected index of GFI and this index is 0.93 in this model. Relative index of NFI in the present mod el is 0.98 and has good fitness.

Table 3. Direct and indirect effects

\begin{tabular}{|c|c|c|c|}
\hline Impact investigation & $\mathrm{t}$ & $\beta$ & Result of hypotheses \\
\hline $\begin{array}{l}\text { Organizational trust-organizational } \\
\text { commitment }\end{array}$ & 5.18 & 0.45 & Organizational trust is effective on organizational commitment \\
\hline Organizational trust-organizational silence & -8.26 & -0.64 & Organizational trust is effective on organizational silence \\
\hline Organizational trust-job satisfaction & 4.21 & 0.39 & Organizational trust is effective on job satisfaction \\
\hline $\begin{array}{l}\text { Organizational trust-Silence } \\
\text { Organizational-job satisfaction }\end{array}$ & 4.19 & 0.29 & $\begin{array}{l}\text { Organizational trust is effective on job satisfaction via organizational } \\
\text { silence }\end{array}$ \\
\hline $\begin{array}{l}\text { Organizational trust-Silence } \\
\text { Organizational-organizational commitment }\end{array}$ & 4.55 & 0.29 & $\begin{array}{l}\text { Organizational trust is effective on organizational commitment via } \\
\text { organizational silence }\end{array}$ \\
\hline $\begin{array}{l}\text { Organizational Silence-Organizational } \\
\text { commitment }\end{array}$ & -5.12 & -0.45 & organizational silence is effective on organizational commitment \\
\hline Organizational silence-Job satisfaction & -4.46 & -0.45 & organizational silence is effective on job satisfaction \\
\hline
\end{tabular}

\section{Discussion and Conclusions}

The results of analysis of main model of study showed that organizational trust had direct effect on organizational silence, organizational commitment and job satisfaction and via mediating variable of organizational silence had indirect effect on two dependent variables, organizational commitment and job satisfaction of present study. According to the results of final model of study, we can explain the relations between main variables, organizational trust and organizational silence with job satisfaction and organizational commitment. Based on the results, trust had direct effect on organizational salience (-0.64). Thus, first hypothesis is supported. It means that the weaker the trust between employees and with top managers of organization, this leads to fear of expression of views, lack of presenting recommendations to promote organization goals and finally employees silence. Also, organizational trust has positive and direct effect on 
commitment and job satisfaction as $(0.45),(0.39)$. Thus, second and third hypotheses are supported. By promoting trust in organization, satisfaction of employees of their job and to the organization they work is improved and employees can be committed to the organization. Based on the main model of study, organizational silence has direct effect on dependent variables of organizational commitment and job satisfaction $(-0.45)$. Thus, sixth and sevenths hypotheses are supported. Lack of these two variables is outcomes of organizational silence in organizations. Indeed, distrust among employees and supervisors and top managers based on main model relations had indirect effect via mediating variable of organizational silence on commitment and job satisfaction, can lead to different silences as obedient silence as avoiding ideas, information or views based on giving up and satisfaction to any conditions or defensive silence as fear in a person to present negative outcomes and information or friendly silence as avoiding the ideas, information or relevant work views with the aim of benefits of other people in organization. This phenomenon reduces motivation and job excitation and work satisfaction among employees and finally commitment of people to organization, job, co-workers and even top managers can be reduced. According to the results in Table 3, fourth and fifth hypotheses, the effect of trust on satisfaction and organizational commitment via organizational silence are supported.

The results of data analysis showed that there was an inverse and significant relationship between organizational trust and organizational silence. These findings are consistent with the results of stud y of Partonia (2014) and Binikos (2010) regarding the significant and inverse relationship between organizational trust and its components with organizational silence. One of the most important factors of integration is dynamics and improvement of trust morale among the employees. The organization with trust among the employees is successful in promoting its goals. As shown, trust plays important role in consistency among human being and organizations and has special position. Trust enables the organization focusing on long-term activities and can be a necessary element for effective change of organization. If organization managers attempt to increase employees trust, they don't observe the silence of employees and their passive behaviors to the changes occurred inside and outside organization. The results of study showed that there was a positive and significant relationship between organizational trust and job satisfaction and organizational commitment. These findings are consistent with the results of study of Khorshid and Yazdani (2012), Kalvey (2007), Sheik-Mohammad et al., (2012), Bakiu (2013) and Kili et al. (2013) regarding the significance of the relationship between organizational trust, job satisfaction and organizational commitment. Indeed, organization trust is one of the components of improvement of organizations performance and if managers have accurate perception of it, it leads to job satisfaction and employees commitment. The systematic perception provides basic organizational trust for exact prediction of dependent variables, job satisfaction and organizational commitment. Organization life and its survival depend upon strong relation between components and constituents. The distrust in job satisfaction has adverse impact on collaboration morale. Also, the results of study showed that there was an inverse and significant relationship between organizational silence with job satisfaction and organizational commitment. These results are consistent with the study of Danayifard and Panahi (2010) and Denis et al. (2013). Organizational silence means the lack of opinion of employees in organization due to some reasons as fear of punishment and rewards for ideas and the lack of belief of manager in employees or the fear of endangering the job situation. Organizational silence is a dangerous phenomenon as a barrier to innovation, organizational changes, continuous improvement, suitable feedbacks, organizational knowledge management, improvement of organizational errors, internal satisfaction of employees and correct decisions of employees and causes that organization get used to present methods and be stagnated. There are various factors in organization referring to organizational silence. The most important organizational factor is management style. Management style of organization and his tendency to dictatorship styles and his attitude to human being is effective on organizational silence amount from this aspect that how much they consider their employees as developed. Indeed, the more the organizational silence broken, the employees can have high opportunities to present their own views and their job satisfaction and job motivations are increased. There is a negative and significant relationship between organizational silence and job satisfaction. The higher the organizational silence, the lower the job satisfaction. Organization silence is a phenomenon in which organization employees avoid opinions regarding organization issues and are silent. Silence is a very important sign, stress or fear in organization and the managers should eliminate the reason in the first opportunity. Ignoring this issue can lead to adverse events, even organization death. The supervisor attitude to silence, management attitude to silence and communicative opportunities as raised silence components are effective on job satisfaction of employees. Human resources dedicate their major part of life to organizational environment. The awareness to employees is of great importance. The investigation of job attitudes of employees in various organizations due to considerable results on improvement of organizational behaviors have received much attention by researchers and authorities of organizational behavior management and human resources management and each organization always attempts to be aware of job attitudes of employees to lead into their 
job satisfaction in organization and establishing positive work conditions. Organizational silence is associated to restricting effectiveness of organizational decisions and change processes. The important issue of organizations is as most of organizations are sad about the silence of employees and in such conditions, quality of decision making and creating innovation and achieving long-term and strategic goals of organization is reduced. Also, organizational silence by avoiding negative feedback can avoid organizational development and changes and satisfaction and job motivation. Thus, organization cannot correct the mistakes. Thus, based on the silence in organizations, the organization employees are silent regarding the problems and job attitudes of employees as job satisfaction can be decreased.

\section{Limitations of the Study}

The present study is performed on employees of Islamic Azad University of Khorasegan branch in Isfahan and we should be careful to generalize the results to other Universities or other organizations.

\section{Recommendations}

Based on the results and analyses, we can present the following recommendations to increase organizational trust, job satisfaction and organizational commitment and reduction of organization silence:

Planning for holding conferences and speech sessions with trust subject and holding educational courses for managers with meritocracy subject in organization by board of directors and educational experts active in organization.

Formulating suitable rewarding system for employees to creative beliefs and ideas based on their performance and formulating the rules to support the views of employees and encouraging the employees to present creative ideas.

Investment of top managers of organization to implement new and applied ideas of organization employees and making group decisions as permanent and giving importance to work groups and committees in organizations.

Identification of individual and personality features of people to delegate their responsibility and hearing the beliefs of employees and using their proposed solutions in organization performance process.

Holding educational classes for managers and employees with communicative and management skills training subject and training new techniques of management for managers and employees.

The design and publishing of brochure with organizational silence subject and coping methods and designing open and friendly spatial design to establish positive relation among the employees, supervisors and top managers.

\section{Acknowledgments}

My gratitude goes to my supervisor, Dr. Fariba Karimi who helped me in this study. Also, I am grateful of participants of study and those who participated in data analysis and collection. Indeed, without their help, this research was not complete. Finally, my gratitude goes to my Family who supported me.

\section{References}

Bakiev, E. (2013). The influence of interpersonal trust and organizational commitment on perceived organizational performance. Journal of Applied Economics and Business Research, 3(3), 166-180.

Binikos, E. (2010). Sounds of silence: Organizational trust and decisions to blow the whistle. SA Journal of Industrial Psychology, 34(3), 48-59.

Callaway, P. H. (2007). The relationship between organizational trust and job satisfaction: an analysisin the U.S.federal work force. Retrieved from http://www.dissertation.com

Deniz, N., Noyan, A., \&Ertosu, N. (2013). The Relationship between Employee Silence and Organizational Commitment in a Private Healthcare Company. Procedia-Social and Behavioral Sciences, 99(6), 691-700. http://dx.doi.org/ doi:10.1016/j.sbspro.2013.10.540

Ellonen, R., Blomqvist, K., \& Puumalainen, K. (2008). The role of trust in organization innovativeness. $\begin{array}{llll}\text { European Journal of Innovation management, } & 11(2), & 160-181 .\end{array}$ http://dx.doi.org/10.1108/14601060810869848

Fitzroy, T. (2007). The importance of organizational trust. Best advice forum. Retrieved from http://www.articlesbase.com

Horn nord, J., Paliszkiewicz, J., Koohang, A., \& Gołuchowski, J. (2014). Management trust, organizational trust, and organizational performance advancing and measuring a theoretical model. Management and Production 
Engineering, 5(1), 32-41. http://dx.doi.org/10.2478/mper-2014-0005

Jones, G., \& George, J. (1998). The experience and evolution of trust: implications for cooperation and teamwork. The Academy of Management Review, 23(3), 531-546.

Kaneshiro, P. (2008). Analyzing the organizational Justice, Trust, and Commitment Relationship in a Public Organization: Submitted to North central University, University Microfilms. The humanities and social sciences, $14-20$.

Khanifar, H., Moghimi, M., Jandaghi, Gh., \& Zarvandy, N. (2009). Analysis of Relation between Elements of Trust and Organizational Commitment of Personnel (social welfare organization of Qom state and education organization of Qom state). Journal of public Administration, 1(2), 3-18.

Khorshid, S., \& Yazdani, H. (2012). The studying of relationships among trust, reciprocity and organizational identification with considering the moderated effect of organizational commitment. Transformation management journal, 4(7), 62-90.

Lee, C. K., Song, H. J., Lee, H. M., Lee, S., \& Bernhard, B. J. (2013). The impact of CSR on casino employees' organizational trust, job satisfaction, and customer orientation: An empirical examination of responsible gambling strategies. International Journal of Hospitality Management, 3(3), 406-415. http://dx.doi.org/10.1016/j.ijhm.2012.10.011

Maleknia, H. R., Mehrabi, M., Hemati-nejad, M. A., \& Ramezan-nejad, R. (2011). The study of job satisfaction and organizational commitment among the employees of physical education general offices of Lorestan, Guilan, and Qom provinces. Quarterly Journal of sport bioscience researches, 1(3), 42-52.

Mayer, R. C., Davis, J. H., \& Schoorman, D. E. (1995). An integrative model of organizational trust. Academy of Management, 20(3), 709-734.

McKnight, D. H., Choudhury, V., \& Kacmar, Ch. (2002). Developing and validating trust measuresfor e-commerce: An integrative typology. Information systems research, 13(3), 334-359.

Mcknight, D. H., Cummings, L. I., \&. Chervany, N. I. (1998). Initial Trust Formation in New Organizational Relationship. Academy of Management Review, 23(3), 73-90.

Milliken, F., \& Morrison, E. (2000). Organizational Silence: A Barrier to change and development in a pluralistic world. The academy of Management Review, 25(4), 706-725.

Panahi, B., \& Danaeifard, H. (2010). An analysis of employee's attitudes in public organizations: Explanation of organizational silence climate and silence behavior. Transformation Management Journal, 2(3), 2-19.

Partonia, S. (2014). The Impact of Trust on Organizational Silence and Its Challenge in Iran. International Journal of Business Economics and Management Studies, 1(2), 1-18.

Sheik-Mohamed, L., Mohiadeen, A. K. M., \& Anisa, H. (2012). Relationship among Organizational Commitment, Trust and Job Satisfaction: An Empirical Study in Banking Industry. Research Journal of Management Sciences, 1(2), 1-7.

Slade, M. R. (2008). The adaptive nature of organizational silence: A cybernetic exploration of the hidden factory. The Graduate School of Education and Human Development. George Washington University (pp. 64-78).

Vakola, M., Bouradas, D., \& Nikolaou, I. (2011). The role of silence on employees' attitudes "the day after" a merger. Emerald Group Publishing Limited, 40(6), 723-741. http://dx.doi.org/ 10.1108/00483481111169652

Vakola, M., \& Bouradas, D. (2005). Antecedents and consequences of organizational silence: An empirical investigation. Employee Relations, 27(5), 44-45. http://dx.doi.org/10.1108/01425450510611997

Zareematin, H., Taheri, F., \& Sayyar, A. (2012). Organizational silence: concepts, antecedents, and consequences. Iranian journal of management sciences, 6(21), 77-104.

\section{Copyrights}

Copyright for this article is retained by the author(s), with first publication rights granted to the journal.

This is an open-access article distributed under the terms and conditions of the Creative Commons Attribution license (http://creativecommons.org/licenses/by/3.0/). 